\title{
N. T. Wright on Paul the Pharisee and ancient Jews in exile
}

\author{
Steve Mason \\ University of Groningen Oude Boteringestraat 38, 9712 GK Groningen, The Netherlands \\ s.mason@rug.nl
}

\begin{abstract}
This article examines two topics that emerge from N. T. Wright's Paul and the Faithfulness of the Gospel: Paul the Shammaite-zealot and the 'great narrative' of an Israel in exile, waiting for something. The perspective adopted is that of a historian, for whom the fundamental question is whether Wright's accounts approximate plausible reality two thousand years ago. With respect to the first topic, analysis of source material on the Pharisees in the pre-70 period renders Wright's association of Paul with the rabbinic 'House of Shammai' and zealotry doubtful in every part. Similar issues arise in relation to the second topic, where Wright's proposal is supported by a kind of proof-texting, without methodical concern for the nature, context, coherence, themes, rhetoric or meaning of texts in situ.
\end{abstract}

Keywords: exile, Josephus, Paul, Pharisees, N. T. Wright, zealot

Though it is a response to part of N. T. Wright's Paul and the Faithfulness of God (2013), the following article should not be mistaken for a book review. Best practice in that genre would require an initial summary of the work, for example, which I cannot attempt here. I drafted this in preparation for the Society of Biblical Literature's 2014 Annual Meeting, where the Pauline Soteriology Seminar was going to welcome the book in a special session. It would be the usual kind of academic welcome: rough handling by a panel, followed by a response from the author and open discussion. The Seminar's Ephors (below) invited me to probe Wright's handling of ancient Judaism, the foundation for his interpretation of Paul. So I wrote out some thoughts in a midrashic series, sent them to Tom in advance, and offered a précis on the day. Iain Torrance then kindly invited me to write a summary for SJT, which I was happy to do. But the confined space of a journal article requires more in the way of an argument than ad hoc observations. So I pulled forward two topics that seemed both important for the book and partly manageable: Paul the Shammaite-zealot and the 'great narrative' of an Israel in exile, waiting for something. 
My questions are those of a historian. Most basically: does Wright's account approximate plausible reality two thousand years ago? Answering that question turns on one's interpretation of evidence and the adequacy of one's explanation. We must travel light here. Many will know something of Wright's larger project, other parts of which my fellow-panelists addressed. I hope to have included enough from Wright to make my responses fair and clear. More or fuller documentation would have required an extra suitcase, which the airline prohibits.

\section{Pharisees at the departure gate: Paul the Shammaite-zealot?}

Paul once refers to some sort of Pharisee connection in his past (Phil 3:5:

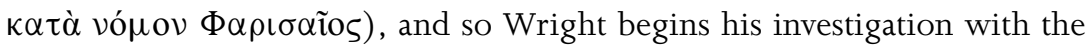
Pharisees. He agrees with a common view that pre-70 Pharisees were much concerned with purity. For Wright, however, the pre-70 issue underlying the purity issues debated by Pharisees in later rabbinic literature was actually political: 'how to be a loyal Jew faced with pagan oppression from outside and disloyal Jews from within' (p. 83). Purity was really 'a sign and seal of that concern' about foreign interference. Moreover, 'In our period, it was the revolutionary wing of the Pharisees who were in the ascendancy ... firmly in the driving seat until devastated by the fall of the city and the Temple' (p. 83), and Saul/Paul 'was trained in this most strict of Jewish worldviews' (p. 84). This radical wing, which would be fully realised in the wartime Zealot faction wiped out in 70, was based in what rabbinic literature calls the house of Shammai. They opposed the accommodations of foreign rule reflexively favoured by the house of Hillel. 'The deep division among the Pharisees themselves, between the houses of Hillel and Shammai, almost certainly focused on this issue' of response to gentiles (p. 85, emphasis added).

The Pharisees' zeal was inspired by the biblical story of Aaron's grandson Phineas, who ran through Zimri and his Midianite wife after Moses ordered that Israelite chiefs found consorting with Baal-Peor be impaled (Numbers 25). The Hasmonean patriarch Mattathias, another priest, in whom the author of 1 Maccabees finds Phineatic inspiration for holy murder (1 Macc 2.23-7), was a more recent model of such divinely authorised zeal. This pedigree of pre-war zealotism may be familiar from the work of W. R. Farmer and M. Hengel, but Wright finds it crucially in Paul's references to his own former $\zeta \tilde{\eta} \lambda$ os (Phil 3:.6; Gal 1.13). Says Wright, "This is what “zeal” was all about. ... And "zeal" is precisely the word that Paul uses of his former self' (p. 85). That is why we must understand Pharisaic-Shammaite zeal if we are to understand Paul's original mindset. 
Let us look more closely. Wright says of the purity concerns ubiquitous in rabbinic texts (eating food in priest-like purity, tithing, holy days, family relations): 'the signs indicate that this is a re-reading of earlier debates which may have been about quite other things' (p. 85). He does not really explain these compelling signs, or indeed treat gospel evidence for similar Pharisaic concerns (Mark 7; Matt 23). With a couple of sentences, nevertheless, the subjunctive may have gives way to near certainty:

the principal debate between Hillel and Shammai ... is almost certain to have been not about purity ... but about how to be a loyal Jew under an alien regime, whether that of Rome ... or compromised local regimes like Herod's. Should one find a way to live and let live? Hillel thought so ... Shammai almost certainly thought not ... (p. 85, emphasis added)

Wright seals the sure foundation with his claim that Paul 'had almost certainly been on the Shammaite side' (p. 86, emphasis added), blithely punting Acts' claim (22:3) that the apostle (-ish) 'was educated in the ancestral law with precision at the feet of Gamaliel' - the most famous Hillelite. Wright's justification seems to rest on faith: 'It is inconceivable, frankly, that someone from the more conciliatory wing ... would have taken the trouble to persecute the emerging Christian movement' (p. 86). But the ground is secure: 'it is against that [Shammaite] background that we must imagine all his rethinking and reworking of prayer, thought and life to have taken place' (p. 86).

The near certainty that Wright professes may be consoling to some, but it unavoidably presses a historian's buttons. Where is he getting this? Wright shores up his picture of Pharisaic principles from the rabbis with other texts that he takes to indicate the group, though they do not appear by name (pp. 82-3, 127), as diverse as Philo of Alexandria and the Psalms of Solomon.

His portrait of the Pharisees takes me back to possibly happier days, when historians of the Pharisees were fairly certain of many things. Though not old enough to recall the controversies of the nineteenth and early twentieth centuries, I did immerse myself in them for my dissertation (1986), and published a summary essay. ${ }^{1}$ Here is the essence. For long decades, confident knowledge about the Pharisees produced fierce debates, because different scholars were sure of different things. In that period, scholarship was still religiously framed, after the gradual 'emancipation' of Europe's Jews enabled their scholars to challenge long-secure Christian portrayals, or slanders. The former tended to see the Pharisees as estimable forebears,

1 Cf. S. Mason, 'The Problem of the Pharisees in Modern Scholarship', in J. Neusner (ed.), Approaches to Ancient Judaism, vol. 3 (Atlanta, GA: Scholars, 1993), pp. 103-40. 
whereas the latter viewed the group through NT lenses, hence disparagingly, approaching also rabbinic literature (if they did at all) with gospel strictures ringing in the ears. These debates were also suffused with values-questions popular at the time, for example about what was gesund (progressive law, red-blooded nationalism, indomitable courage against foreign predators) or krankhaft (other-worldly escapism, especially, but also any over-fondness for libraries, scrolls or detached mental worlds) in religion. And beneath everything else was a disagreement about sources: the weight given to the gospels, the disposition one should bring to rabbinic literature and the collision between the irresistible force with which experts declared Psalms of Solomon, Jubilees, Testament of Moses, or a pre-Qumran Damascus Covenant Pharisaic and the immovable objections of others. Supreme confidence on all sides produced impressive fireworks but little enlightenment.

In the less parochial times since the 1970s, with the growth of secular religious studies and university-housed Jewish/Judaic studies, we have reached a happier state of admitted ignorance, but with the upside of agreed historical principles. With the fundamental work of J. Neusner, E. Rivkin, A. Saldarini, E. P. Sanders and many others, research moved in a more disciplined, collaborative, publicly accessible direction. The main characteristics of this were the limitation of admissible evidence for the Pharisees, in the first instance, to texts that mention the group and offer hope of contemporary access (viz., NT authors, Josephus and early rabbinic literature), and an increasingly recognised need to understand the nature and usefulness of each text, even if that complicates historical reconstruction. ${ }^{2}$ We can easily explore the Pharisees of Matthew, Luke-Acts, Josephus or early rabbinic literature, because they are present before our eyes. We cannot examine the Pharisees of Psalms of Solomon or the Qumran Scrolls in that way, because they do not exist. As we progress from evidence interpretation to speculation about the real Pharisees, to be sure, we might wonder whether some of them were the 'seekers after smooth things' in Qumran texts, or whether a Pharisee wrote Psalms of Solomon or Testament of Moses. But that belongs with imaginative hypothesising rather than the interpretation of our evidence. To find Pharisees in such texts we would already need to know some absolutely distinctive traits.

Wright's use of Philo (De Specialibus Legibus 2.253) for the Pharisees illustrates this problem. He says: 'We should be in no doubt that he is referring to Pharisees, and moreover to "zealous” ones like Saul of Tarsus' (p. 83, emphasis added). The passage is important for his view of the Pharisees' impact: 'Philo makes it

2 The clearest example is J. Neusner and B. Chilton (eds), In Quest of the Historical Pharisees (Waco, TX: Baylor UP, 2007). 
quite clear that a strong part of the Pharisees' aim was not just to try to influence other, non-Pharisaic, Jews but to put considerable pressure on them to shape up, to approximate to their own high levels of purity.' Thus Wright can speak of 'Philo's fascinating window on zealous Pharisaic activity'. From Wright's confidence one would think that Philo actually mentioned Pharisees. Wright's warrant for finding them in the Special Laws is unclear, but seems to involve words that Wright considers tellingly Pharisaic. In a context we are about to consider, Philo says: 'Myriads of overseers (ephors), $\zeta \eta \lambda \omega \tau \alpha i$ of the laws, very scrupulous guardians of the ancestral ways, act mercilessly against any

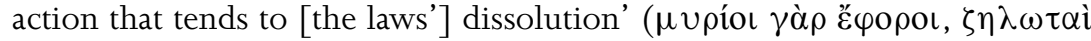

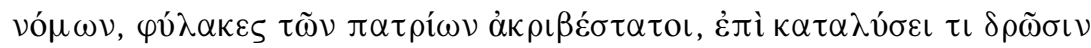

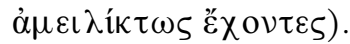

If Wright finds Pharisees here because of external parallels with a couple of words (one of the hazards of our trade), he ignores cues that Philo himself offers about his meaning. As we know, $\zeta \eta \lambda$ - words in common Greek discourse (outside the LXX) had to do with devotion to or emulation of someone or something admirable, not zeal as such. Recall Josephus' happy days as the disciple ( $\zeta \eta \lambda \omega \tau \eta \dot{\zeta}$ ) of Bannus (Life 11; cf. Antiquities 20.47; Apion 1.162). His $\zeta \eta \lambda \omega \tau \alpha i$, whom he assails for their poor judgement in choosing objects of emulation, would give 'zealots' a bad name in modern languages. The word by itself connoted something admirable, as we see with all those philosophers who admired Sparta's constitution (Plato, Prot. 342e-343b). Josephus and Philo substitute Judaean for Spartan law, as the system most durably admired and emulated by others. Indeed, Philo's use of ephor might be a nod to the Spartans, who distinctively entrusted their leadership to Ephors. He uses the word twenty-five times, usually of God or 'Justice' as the Overseer who watches human affairs and does not permit evil to go unpunished (Spec. 3.19, 129; 4.200). In our passage the guardian-overseers are myriad, but the idea is the same. Given Philo's clear statement that those who blaspheme will meet the ephors/guardians' punishment 'even if they should escape retribution from humans'

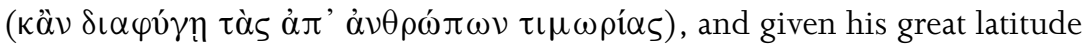
for intermediary beings, why should we think that these guardian-overseers are even human, let alone Pharisees?

Philo also uses $\zeta \eta \lambda$ - terminology often, most typically to contrast worthy (Mosaic) with unworthy (Egyptian or vice-ridden) objects of emulation. He has $\zeta \tilde{\eta} \lambda$ os forty-four, $\zeta \eta \lambda$ ó $\omega$ fifty-five and $\zeta \eta \lambda \omega \tau \eta \dot{s}$ twenty-seven times, and all cognates at least 138 times. In the Special Laws alone he uses $\zeta \eta \lambda \omega \tau \eta \dot{S}$ nine times, the word group thrity-one times. Moses, he says at the first occurrence, concerned that $\zeta \eta \lambda \omega \tau \alpha i$ of his matchless laws might be swept away in the stronger current of baser devotion, took care to provide a lofty conception of God and piety for emulation (1.30, 133; 2.230). 
Most people remain, alas, $\zeta \eta \lambda \omega \tau \alpha i ́$ of lust, dissipation and evil (2.170, 240). In our particular passage, Philo is warning about the iron severity of Moses' laws. If people casually misuse the divine name in their oaths, though they escape human punishment, there are tens of thousands of overseers (ephors) and guardians, $\zeta \eta \lambda \omega \tau \alpha i$ of these laws, who will bring retribution. Imagining these ephors/guardians/devotees alone as Pharisees, without any warrants from the text or Philo's context, seems to be quite unnecessary for understanding the passage and unhelpful as an explanation of it.

We cannot pursue this level of detail for every passage Wright offers. I am trying only to illustrate a methodological problem. What is the explanatory power of Wright's proposals?

We move from Philo's Pharisees to pre-70 Pharisaic houses. Neusner has spent much of his astonishing career translating and interpreting the major rabbinic corpora. On a grand, systematic scale he has done what I have only hinted at with Philo: examining the structure and rhetoric of each text in its own time and circumstances. This procedure tends to complicate or exclude the old efforts to break loose elements of a text as though they were free-standing data, unburdened by the work that created and housed them. Already in 1971 Neusner was spelling out some implications for historical research on the Pharisees, including the houses of Hillel and Shammai. His conclusions are worth recalling here:

The focus of interest of the rabbinic traditions about the Pharisees is the internal affairs of the Pharisaic party itself. The primary partisan issues center upon Shammai's and his House's relationship to Hillel and his House. ... Essenes and Christians make no appearance at all. ... The country's life and struggle with Rome as a whole are bypassed in silence. What we have, therefore, are the records of the party chiefly in regard to the life of the party itself. ... This seems to me the most striking result of the survey. ${ }^{3}$

One might see no immediate conflict with Wright, who acknowledged parts of the rabbinic presentation but imagined a different earlier reality. The problem is that Neusner took it for granted that the two-houses model, with its mnemonic formulae of contrast (House-of-Shammai says X, whereas House-of-Hillel says Y), was a rabbinic construction of the Yavnean period. It would not have made sense earlier. Before 70, each group must have generated its own legal interpretations; it could not have waited to hear what another group said, merely to contradict it, but must have produced rules for its own life (cf. Qumran). He further argued that the Hillelites,

3 J. Neusner, The Rabbinic Traditions about the Pharisees Before 70, 3 vols. (Leiden: Brill), vol. 3, pp. 240, 304 (emphasis added); similarly pp. 227, 234, 248. 
ascendant at Yavneh, exploited the two-houses construction to provide a negative foil for their man. ${ }^{4}$ Shammai's image of stubborn severity was just one result: he can also appear as weak, more stringent than his 'house', or even as a deceptive 'crypto-Hillelite'. ${ }^{5}$ The artificiality of the rabbis' twohouses construction was clear to Neusner also from the way Beit-Hillel and Beit-Shammai contend for control of the sacrificial cult, as though priests did not exist - much as the high priests disappear from the rabbinic 'Sanhedrin' . 6

Neusner's Bibliographical Reflections included scathing assessments of earlier scholars' naïve use of this material: '[I]n general, the historical question has been asked too quickly and answered uncritically." ${ }^{7}$ Of Heinrich Graetz's picture of the School of Shammai as uncompromising rigorists against yielding Hillelites he remarks: 'This repertoire of lugubrious homilies masquerading as historical facts set the fashion from Graetz's time onwards.' And he castigates Rabbi Samuel Mendelsohn’s ‘even more gullible approach', which portrayed Hillelites as 'peace-loving men, accommodating themselves to circumstances' and Shammaites as 'stern and unbending like the originator of their school', as intensely patriotic, Zealot-like rejectionists of foreign rule. $^{8}$ Neusner further showed that the concept of Oral Torah from Sinai, which again Wright takes to be a central concern of pre-70 Pharisees (p. 176), was thoroughly rabbinic and not likely Pharisaic. ${ }^{9}$

This is what I mean by déjà vu. Old houses that have stood the test of time win our affection, but these particular, pre-70 houses were demolished for being poxed and unsound. If Wright wishes to rebuild them, I think he needs to explain that he is doing so, on what basis, and where one may secure a permit to join in the construction. To change my clumsy metaphors, Wright is asking us to climb a ladder of propositions: that the two houses, though mentioned only in the third-century Mishnah and later, were already recognisable as a pair before 70; that their chief concerns, in spite of the hundreds of rabbinic comparisons on in-house legal disputes (or the Gospels), actually had to do with foreign rule; that in this regard Shammaites were radical rejectionists, Hillelites reflexive accommodationists; that Paul, in spite of Acts' meagre evidence, came up as a Shammaite; and that we can only truly understand Paul when we have ascended this ladder of insights. As I try to climb with our genial host, however, I find the lowest rung already insecure, so I cannot go higher. It seems considerably easier to understand

${ }^{4}$ Ibid., pp. 313-17.

${ }^{5}$ Ibid., pp. 312-19.

6 Ibid., p. 314.

7 Ibid., p. 322.

8 Ibid., pp. 334, 338.

9 Ibid., pp. 163-79. 
rabbinic literature, Philo, Qumran Scrolls, Josephus and Paul, who never hint at Wright's complicated apparatus, without it.

As for the prospect that Pharisaic 'zeal' against foreigners led to war, I would observe that Josephus, who carries no water for Pharisees, gives a very different picture. His account of the war ignores Pharisees altogether notwithstanding Antiquities' passing mention (18.4) of a Pharisee connected with protests two generations earlier - and he says nothing of houses. His Z $\eta \lambda \omega \tau \alpha i$, a name he toys with in Philo-like ways (as devotees of the wrong people and values), are a priestly group based in the temple. They are associated initially with the high priest's son Eleazar ben Ananias, later with Eleazar b. Simon and John of Gischala (War 5.5-7, 12, 21, 99-105, 250-1). That first Eleazar, commandant of the temple, led the rejection of gifts from foreigners in the summer of 66, and his faction massacred the auxiliary garrison. The last we see Pharisees as a group in War, their leaders are vociferously opposing these fateful priest-led moves (War 2.409-26, 450-3; Life 21-2). One prominent named Pharisee (Simeon b. Gamaliel) and the likely Pharisee Joseph son of Gorion appear alongside the chief priest Ananus II leading the early coalition (Life 189-94; War 2.563), which aims however to wind down the revolt. ${ }^{10}$ At any rate the Gorions oppose the Zealots and soon die at their hands. ${ }^{11}$ From Josephus one could rather gain the impression that the most energetic militants in at least the early phases were priestly groups, perhaps inspired by their ancestors Phineas and Mattathias. And none of the later main players - John of Gischala, Simon bar Giora, Idumaeans, Adiabenians had any closer connection with Pharisees. The whole Pharisee/zeal-againstforeigners/Shammaite school/Paul nexus therefore seems doubtful in every part.

\section{A great narrative of exile?}

Similar issues arise in relation to our second question: a proposal supported by a kind of proof-texting, without methodical concern for the nature, context, coherence, themes, rhetoric or meaning of texts in situ. Wright seems to justify his eclecticism with the notion of a single great narrative that virtually all ancient Jews inhabited, and Pharisees in particular. This was implicit everywhere and occasionally pokes through the surface geyser-like, even if no significant text actually lays it out. To borrow a metaphor Wright uses in relation to Paul, the varied Jewish texts are perhaps 'bucketfuls of water drawn from a deep well', and he is after the well - the allegedly shared

10 Ananus was reportedly the implacable enemy of the Zealots as well as Simon bar Giora (War 2.651-54), eventually falling victim to the former (4.314-25).

11 War 2.4.159, 358. 
worldview - rather than the buckets (pp. 29-30). ${ }^{12}$ In his own words, 'there is every indication that the kind of Jew who became a Pharisee was implicitly aware of living in a continuous story going back to Abraham, perhaps even to Adam, and on to the great coming day, and of being called to be an actor within that drama' (his emphasis), and so Paul should also find his place in this 'great controlling narrative'. ${ }^{13}$

What is the narrative? Wright conjures a biblical-Jewish story of Israel's perpetual exile and hope of restoration. He finds this grounded in Deuteronomy 27-30, picked up in the covenantal language of Daniel 9, and embraced by Josephus among others. Thus:

The point $\ldots$ is the theological awareness of being at a particular stage within the overall continuing narrative, coupled with the exegetical awareness of a large-scale Deuteronomic prophecy being worked out. . . . The idea of continuing exile is, I believe, part of the 'Sanders revolution' in Pauline studies (or second-Temple Jewish studies), but a part that neither Sanders himself, nor Dunn for that matter, ever worked out (though the texts were there to tell them they should). (p. 140, emphasis at end added)

This final remark creates a certain tension, which we cannot explore, between Wright's insistence that the great narrative is plainly already there in our texts and other passages in which he explains that it is more of a metanarrative (pp. 114-16). Wherever the line between those should be drawn, we should understand that it was in a Pharisee's 'bloodstream', and so in recovering it we are touching 'some central components of the mindset of Saul of Tarsus' (p. 108). Like the radical Shammaites, this is a matter of 'enormous importance' (pp. 150, 175). Wright elaborates:

Perhaps we can get at the heart of what I am saying like this: that within the continuing narrative which virtually all Jews believed themselves to be living in ... a great many second-Temple Jews interpreted that part of the continuing narrative in which they were living in terms of the so-called Deuteronomic scheme of sin-exile-restoration, with themselves somewhere in the middle stage, that of 'exile' (which, granted, could itself become quite complicated). (p. 140)

12 Wright uses 'great narrative' nineteen times, 'grand narrative' five times (including contrasts with a contrasting grand Roman narrative of imperial salvation, which also seems to me very doubtful). 'Single' is implied throughout and occasionally explicit (as on pp. 138-9).

13 E.g. p. 97. Wright uses 'controlling narrative/story/metaphor/categories' dozens of times, arguing also that Paul's controlling categories came from those of Judaism. 
Further:

[Ancient Jews] knew that, despite the geographical 'return' in the late sixth century and on to the time of Ezra and Nehemiah in the mid-fifth century BC, something they still regarded as 'exile' was not yet over. And they were reading their own situation, again and again, within the single flow of national narrative which they found in Deuteronomy 27-30. This combination of Daniel's revised prophecy ... and the Deuteronomic warning of the curse of exile followed by the blessing of covenant renewal is, I suggest, at the heart of the controlling story within the worldview not only of first-century Pharisees but of a great many other second-Temple Jews as well. (p. 146)

Wright acknowledges that many scholars have doubted this, while naming individual supporters (p. 146). Not being party to those earlier debates, I can only offer my assessment.

First, the notion of a controlling narrative seems curious. I first heard the term 'controlling', outside personal relationships, when studying with Ben Meyer, who favoured it. Because he understood history as the investigation of problems, which set the terms of inquiry, he often used 'controlling' to describe the questions, assumptions, frameworks, ideas and biases that shaped what any investigation could produce. He also spoke of controlling themes, as redactional-compositional motifs that shaped an author's material. All that I understand. But is control a function of stories, with their meandering plots and endless possibilities of interpretation and subtext? It is one thing to tell the story of Abraham's near-sacrifice of Isaac or Jacob's tricks against Esau, another to say that the narrative means X or controls Y. Greek authors would frequently cite a line from Homer or a tragedian. Those were canonical works, authoritative, intensively studied, the core deposit of the common cultural fund. But how were they used? In keeping with rhetoric's ubiquitous values, they were resources to be turned in new and unexpected ways, to the delight of audiences. As far as I can see Judaean writers took a similar approach. Abraham, Moses, Saul, David and Solomon were not figures with stable or controlling meanings, which needed to be learned. Philo, Josephus, the pesharists and the rabbis fashioned new and exciting figures from the familiar repertoire: philosophers, exorcists, natural scientists, or examples of masculine virtue. Since Paul and the evangelists furnish so many examples of the same freedom, I do not see how a narrative could have issued such propositions, requiring understanding and assent, as 'continuing exile'. More pertinently, I cannot see this in or behind our main first-century texts.

Wright may exacerbate the problem when he writes: 'The widely differing ways in which the story was told demonstrates that out of the hundreds of features that were in principle available every writer could pick and choose to present his 
own points' (p. 135, emphasis added). If there were hundreds of features to choose from, who was in control: the narrative or the writer? Since it was not a matter of merely picking and choosing, but of liberal supplementation and alteration, as we see in Josephus' biblical paraphrase, where is the controlling aspect of the narrative?

I sometimes worried that I was taking Wright's language too literally. But he reasserts the claim in various ways. It is as though, he suggests in one place, ancient Jews pulled a book called 'My Life' from the library shelf, saw that it was volume 99 of 100 , and realised that they needed to read the earlier volumes to grasp their place in the narrative (p. 116) - not a uniquely individual place but everyone's place in the story. The Bible 'presented itself as a single, sprawling, complex but essentially coherent narrative, a narrative still in search of an ending' (p. 116). The story could even answer specific questions, generically for all (p. 150, emphasis added):

What then does 'exile' mean, in this continuing sense? Answer: the time of the curse spoken of in Deuteronomy and Leviticus, a curse that lasts as long as Israel is 'the tail and not the head', still subject to the rule, and often the abusive treatment, of foreign nations with their blasphemous and wicked idolatry and immorality, not yet in possession of the promised (even if laughably ambitious) global sovereignty. As long, in other words, as the condition of Israel is much like that in Egypt, they will be waiting for the new exodus.

It is in trying to nail down this 'exile' that I meet problems, general and particular. First the general. On the one hand, as the paradigmatic Phineas episode shows, Israel had been subject to foreign harassment, threat, and/or domination since before the conquest of Canaan, certainly since the NeoAssyrian period. Even the Hasmonean state lived half of its life (160s to 120s or later) under fading Seleucid rule. If the nation was always in some kind of 'exile', even when not in Exile, what force does the term have? Was there a conceivable alternative?

On the other hand, in spite of the drift of much recent NT scholarship I rather think that the first century of Roman hegemony represented Jerusalem's salad days. Josephus remarks on the city's unparalleled eudaimonia at this time (War 1.11). More populous and prosperous than it ever had been or would be until the late Ottoman period, world-famous Jerusalem dominated Coele-Syria for more than a century, and Judaeans punched well above their weight. Their leaders were uniquely close to Rome's rulers, from Julius Caesar and Marc Antony through Augustus to Claudius. It is true that we do not have comparable evidence for Samarians, Ascalonites, Idumaeans, Egyptians or Gadarenes, but what we do have (Josephus, Philo, Gospels, coins) suggests that the others had nothing like the access of an Agrippa 
I or II. Judaean minority communities also prospered, enjoying significant exemptions (from conscription; permission to send funds to Jerusalem; local protections for their foreign customs). We can always complain, but Judaeans were not in a situation remotely comparable to the storied slavery in Egypt. And it is hard to find traces of exile-anxiety in first-century texts. Philo and Josephus register fear or outrage at certain moments of vulnerability, but they write as culturally confident members of an eastern elite. Josephus uses the return from Exile, full of promise and glory, as the central pivot of his Antiquities (books 10-11), giving no hint that exile has somehow continued.

In every society certain subcultures, genres and periods lend themselves to expressing alienation or social criticism. We do not expect the US Air Force choir to sing Leonard Cohen's 'Democracy is coming to the USA', or 'There'll be the breaking of the ancient western code ... phantoms ... fires on the road'. Apocalyptic genres and styles, some in verse, continue to voice displacement, grievance and even vengeance. Perhaps there is something in William James' distinction between 'world-affirming' outlooks - Philo, Josephus and the rabbis - over against the 'religion of the sick soul' and the twice-born. However that may be, alienation and grievance were and are hardly unique to Jews, as the literature of disaffected Egyptians shows. The ancient Jewish examples generally lament the success or the loss of Hasmonean power, generations before our period, or the fall of Jerusalem afterwards. ${ }^{14}$

Paradoxically, in view of Wright's case that a pervasive Jewish sense of exile was resolved for Paul in the experience of Messiah, one might conclude as easily that alienation was programmatically Christian, not Jewish. Was Paul not one of the most dislocated figures of Western history? 'We who are alive ... will be caught up in the clouds ... to meet the Lord in the air'; 'Let those who deal with the cosmos be as though they had no dealings with it, for the form of this cosmos is passing away.' Christ will 'deliver us from this present wretched aeon'. I pray 'that you might remain utterly pure and blameless for the day of Christ', for 'our politeuma is in the heavens, from where we are awaiting a saviour'. Exile seems more characteristic of the stream that issued from (and moderated) Paul because of the sharper dualisms engraved in these canonical texts. A discourse of dislocation runs from Paul, Hebrews, the synoptic apocalyptic discourses and Revelation via Augustine's City of God to modern spirituals ('Going home'; 'This world is not my home'; 'crossing the Jordan'). The Christian mainstream was definitionally in suspense as it awaited the Second Coming (cf. Justin Martyr, Dialogue with Trypho 32), hence fundamentally at odds with the polis life that made the rest of the world work.

14 From Psalms of Solomon and some Qumran texts to 4 Ezra and 2 Baruch. 
Granted that some Jews yearned at times for an anointed figure to save the day, others (as Philo and Josephus) fully engaged high culture and celebrated the success of Torah among the world's constitutions.

I agree with Wright completely that not everything people believe can be explicit in texts. Authors rely on specific audience knowledge (hence irony and satire) and the shared values of a larger discourse (langue) to communicate. E. P. Sanders' elucidation of 'covenantal nomism' famously argued from what was beneath the texts, not so much in them, though there are notable differences. Sanders devoted whole chapters to his main texts. This allowed him to explore many passages in a single work, sampling the general atmosphere. Second, he was asking about what the texts logically presupposed: they might not discuss the need to observe 'covenant' or offer sacrifice, but if they discuss how best to do so then covenantal (including sacrificial) obligations are presupposed. ${ }^{15}$ Third, what Sanders found by this method was a core of ideas, tenets or commitments: a 'pattern of religion' or theology, not a narrative.

Wright's great narrative does not seem to me derivable either from what the texts actually say or from what they presuppose, in spite of his claim in some places (above) that they show us the narrative. Here is an example from Josephus of his method and my concern:

When Josephus describes the Pharisees as believing in 'synergism', over against the Sadducees who believed in 'free will' and the Essenes who believed in 'determinism', the strong probability, I believe, is that this is Josephus's translation of political reality into apparently harmless philosophical categories. The powerful, aristocratic Sadducees believed that they could do whatever they liked; the disempowered Essenes believed that they simply had to wait for God to act; the Pharisees believed that they were required to work towards bringing God's kingdom ... Those are the three-dimensional versions of the two-dimensional analysis Josephus presents for the benefit of his non-Jewish readers. (p. 181, emphasis added)

Just as he found the rabbis' detailed statements about purity concerns a late transformation of political positions, here he has Josephus doing much the same for all schools, more than a century earlier. Although Wright seems confident ('strong probability'), he does not even divulge which passage, of the three in Josephus that describe the schools (plus Life 10-12), he has in view. The 'synergy' he connects with Pharisees could apply only to War 2.162-6 or Ant. 18.12-22, but the former does not include Essenes, and the

15 E. P. Sanders, Paul and Palestinian Judaism (Philadelphia: Fortress, 1977), e.g. pp. 80-2, 149-50, 182, 223, 299, 330, 339, 421. 
latter describes only Pharisees on fate and free will. So perhaps he means the second passage, Ant. 13.171-3, the only one that places all three schools on a fate/free will spectrum, but this one does not ascribe synergy to the Pharisees. In this exceedingly simple digression from the early Hasmonean narrative, Essenes attribute everything to fate, Sadducees nothing and Pharisees some things but not all (hence no synergy here). The scheme is not very revealing, though such a crude sketch for momentary purposes resembles passages in Cicero (De Fato 39; De Natura Deorum 1.2) and Tacitus (Annals 6.22).

Wright's political explanation could not work for War 2.119-66, which Josephus presents as his definitive statement on the subject (Ant. 13.173, 298; 18.11). That passage is almost entirely a glowing exploration of the Essenes. Hardly 'disempowered', they are his absolute stars, displaying the traits of self-mastery and contempt for death that characterise the nation later in War and Against Apion. Essene pre-eminence leaves only a little see-saw for the other two parties (2.162-4): the Pharisees leap up and shout 'Yes!' to fate and the soul; Sadducees rise in turn to yell 'Oh no it isn't!' In the third passage, Josephus insists that Sadducees were not free to do as they wished, being hamstrung by popular support for the Pharisees (Ant. 18.15, 17; cf. 13.298). It is not only, then, that no ancient reader could have found what Wright considers 'strongly probable' in Ant. 13.171-3, if that is the passage he means. We have reason to doubt that Josephus could have imagined such notions either.

Indeed, Wright sees Josephus as an important post-70 witness to the (meta)narrative of exile:

For our present purposes the main thing is that he [Josephus] is interpreting his own time in the light of the huge, sprawling narrative of Israel's long and chequered career. That he sees the whole thing in terms of a long story reaching a paradoxical resolution (perhaps not yet a conclusion) there should be no doubt. (p. 129, emphasis added)

I conclude this response by considering two passages in Josephus that Wright treats as geysers, loci where the metanarrative breaks through the surface. My point here is not to suggest that 'my interpretations are better than his'. I have provisional views, which have changed and will change again. There is no reason that Wright should know, let alone agree with, them. My question is about how well his reading of the great (meta)narrative in Josephus (and, mutatis mutandis, in other texts) would explain what is actually there. If his perceptions of general exile-feeling do not help to explain the surviving texts, what do they explain? My examples are from War 5 and 6.

The first is one of War's seven or eight set speeches (depending on inclusion criteria), one of two or three delivered by Josephus' character (5.360-423; 
cf. 3.362-82; 6.99-110). Although each oration uniquely suits its occasion and speaker, they play with common themes and rhetorical devices. ${ }^{16}$ In this case the scene is Titus' capture of Jerusalem's second wall. As he ponders taking the temple stronghold, he pauses to have Josephus address those still besieged, urging them to surrender. As in some of the other cases, the speaker first tries a direct and brief appeal. This one is in coldly realist, Thucydidean (not biblical) terms: the Romans are too strong and obviously have fortune/luck/chance ( $\tau u ́ x \eta$ ) on their side (5.367). Since it is a law of nature that the weaker must yield to the stronger, you need to surrender already! Only 'when he could not persuade them with plain counsel' does Josephus reluctantly turn to the statesman's last resort: high-

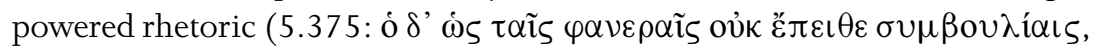

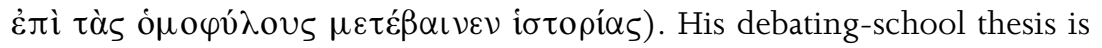
that the national past actually reveals a tradition of pacifism $(5.390,399)$. Who knew? This is pure nonsense, of course. Josephus takes pride in Israel's military successes, even turning Moses and himself into great generals; martial prowess was central to the concept of virtus/ $\dot{\alpha} \rho \varepsilon \tau \dot{\eta}$. He celebrates this aspect of the national character, not least the Hasmonean conquests that made his hero Hyrcanus I so great. In the present speech, however, even the Hasmoneans, whose exploits lay the foundation of the work, must act as failures because they rose against Antiochus IV in arms (5.394). The speech is a tour de force.

Wright discusses neither this context nor War's speeches in general, observing only that Josephus 'is well able to adapt Israel's history for his own purposes' (p. 129). True, but for what purposes? Surprisingly, Wright expresses surprise ('one might have expected') that he did not encourage the besieged to patiently await divine deliverance. But why would Josephus have done that, when he was under orders to urge surrender, and when he portrays only tyrant demagogues as offering such false assurances? In spite of all contextual indicators, Wright finds here 'still the great story of Israel coming at last to a long-delayed climax, albeit a terrible and tragic one' (p. 129).

I suggest rather the speech is more or less the opposite of a shared, familiar narrative. Josephus presents it as his craft, which he produced ad hoc when his real arguments were disdained. Moreover his five examples of successful

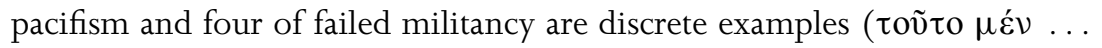

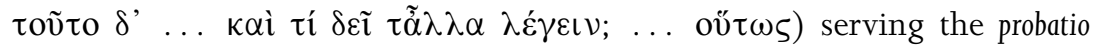
of his argument. His success depends on decontextualisation and misdirection.

16 E.g. D. R. Runnalls, 'The Rhetoric of Josephus', in S. E. Porter (ed.), Handbook of Classical Rhetoric in the Hellenistic Period 330 B.C.-A.D. 400 (Leiden: Brill, 2007), pp. 737-54. 
These distinct proofs have the same function as Agrippa's seriatim mention of Britain, Spain, Egypt and Greece to show that formerly great nations live happily under Roman rule (2.346-404) - also nonsense - and Eleazar's

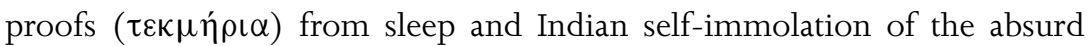
proposition that soul and body are happiest apart (7.341-88). In our case, because the issue is national honour, Josephus conjures up proofs that will move them, giving a few familiar stories from Israel's past a radical new look. And he has some success (5.420-2).

As for Wright's perception of the 'great story of Israel coming at last to a long-delayed climax' in Josephus, the ancient priest certainly considered the fall of Jerusalem a disaster ( $\sigma \cup \mu \varphi \circ \rho \alpha$ ), not a climax to some long exile. Rather, before the war Jerusalem had 'attained a higher degree of prosperity/success/happiness ( $\varepsilon \dot{\delta} \alpha \iota \mu$ oví $\alpha$ ) than any [polis] under the Romans'. The catastrophe was an abrupt reversal of $\tau u ́ x \eta-a$ Polybian, not biblical concept pervading the work ${ }^{17}$ - which despicable tyrants (a Greek category) pushed as far as complete destruction. A narrative of long exile is not merely absent; it would not explain Josephus' language or emphases, or his sanguine outlook shortly after the war.

Secondly, conceding that an exile narrative would be hard to find in Philo, Wright writes:

But read Josephus, and it becomes clear: here are the revolutionaries, he says, who are doing what they are doing because of an oracle in their scriptures according to which at that time deliverance would come to Israel. As I argued before, the only oracle which makes sense ... is the book of Daniel. And Daniel is precisely all about a story ... [in which one like a son of man] will bring about the real return from exile. (pp. 116-17)

Wright has in view Josephus' remark at War 6.312-13 about an ancient oracle. He takes Josephus there to be explaining how the war began:

[I]t is through a single comment that he makes on the Jewish zeal for war ... that we see how the prophetic narrative of the Book of Daniel was being read at the time. What drove them to war, he said, was a biblical oracle which said that at that time a world ruler would arise from Judaea. (p. 293)

But contextual reading again throws up formidable obstacles. Josephus' brief reference to this oracle is part of a much longer digression (6.288315). The temple is ablaze and so Josephus' narrative has reached its climax. Having just described a heinous example of the tyrants' misuse of so-called

17 Cognates appear about ninety times in War, programmatically in the proem (1.11-12, 28). 
prophets, the priestly author stops to reflect on the enormity. He lashes out at Simon, Eleazar and John for having caused the deaths of so many, especially women and children, by deceiving them with fraudulent promises of salvation. To stem desertion, they had cynically enlisted prophet-types. In the worst case, the one prompting the digression, they summoned the people to the temple court, on that day to receive signs of deliverance (6.285-6). And the people all died.

This leads Josephus to broader reflections about the capacity of human beings for self-delusion as they interpret in their favour signs that actually indicate their doom (6.287-8). He offers seven examples from the years before the revolt, a cow giving birth to a lamb or massive gates opening without human action, and occasionally reiterates: the deluded common folk saw a good omen but the few learned ( $\lambda$ ó $\gamma(\mathrm{o})$ ) realised that catastrophe loomed $(5.291,295)$. After these prodigies he says that God provides every possible indication of the future, for their safety, but they stubbornly misread the signals (6.310).

Josephus illustrates with two allegedly misread oracles. The first, plainly

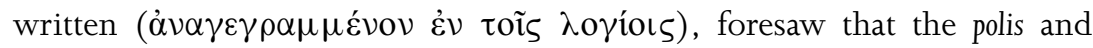
sanctuary would be taken when the temple compound became square. The Judaeans unwittingly achieved this geometry when they (he does not mention the Roman contribution!) destroyed the Antonia fortress (6.311). Whether any Judaeans had the foggiest notion of such an oracle Josephus does not actually say, and since no one has ever found it we are free to doubt. In its present form, this information is for his literary audience in Rome, confirming the author's expertise in oriental arcana.

The second misunderstood oracle is the one that Wright seizes upon and tracks to the great narrative via Daniel. Josephus refers here to an ambiguous oracle ( $\chi \rho \eta \sigma \mu$ ò $\varsigma \dot{\alpha} \mu \varphi$ íßo $\left.\lambda_{0} \varsigma\right)$ in the sacred writings, to the effect that 'at that time someone from their territory would rule the inhabited earth' ( $\kappa \alpha \tau \grave{\alpha}$

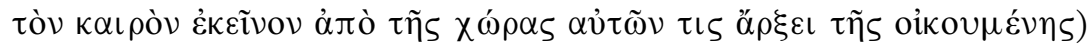

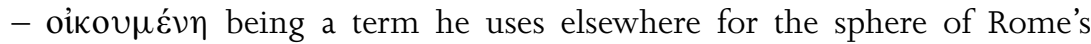
imperium. ${ }^{18}$ Whereas common Judaeans, in this case even many 'wise', took the saying to indicate one of their own (6.313), a conviction that supposedly

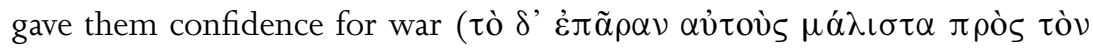
$\pi \delta ́ \lambda \varepsilon \mu o \nu$ ), Josephus nearly alone understood the referent to be their enemy, Vespasian, whom Josephus (not the Flavians) has presented as receiving his imperial acclamation in coastal Caesarea. ${ }^{19}$ He concludes the digression with

18 War 1.355, 633; 2.360, 362-4, 372, 378, 382, 398, 580; 3.29, 473, 480, etc.

19 Vespasian backdated his accession to 1 July 69, when the legions of Egypt acclaimed him (Suetonius, Vesp. 6.3; Tacitus, Hist. 2.79). Josephus insists that he was first acclaimed in 
another recap: if the Judaeans did not ignore these ominous indications altogether, they interpreted them to suit themselves (6.314-15).

Five considerations make it difficult for me to see this putative oracle as evidence of a widely understood narrative, especially one that could have led to war.

(i) It is an oracle: a definitive, one-time, usually ecstatic utterance by a prophet or seer (War 4.386), a term normally used by Josephus of other nations (Ant. 2.241; 9.289; Apion 1.307-12). Oracular utterances as motives for action do not sit easily with the notion of a great guiding narrative. Oracles were not a standard biblical-covenantal mode, aside from the mysterious Urim and Thummim, the medium of Endor, or rare prophetic responsa in particular moments of the distant past. Many decisive events in the Greek past had occurred because of oracular utterances by the seers of Delphi, Thebes and other temples. Many such oracles were straightforward, though ambiguity was part of the art. Most famously, Croesus of Lydia failed to ponder whose empire would be destroyed, as the Pythia foretold, if he attacked Persia (Herodotus, Histories 1.53-4). He, a figure of some interest to Josephus, became the paradigm of hubristic men who assume that oracles are in their favour. ${ }^{20}$ The Croesus model works here: Judaeans allegedly assumed that an ambiguous oracle was about them, and proceeded to war on that basis, but (surprise!) it was really about their enemy, Vespasian. Where is the great biblical narrative?

(ii) The appeal of such a remark to Josephus's Greek and Roman audiences is proven by their borrowing (apparently) of this item and little else from Josephus. It suited a Roman perspective to see the Judaeans as crazed, superstitious Middle Easterners who foolishly rose against Rome on account of some nutty religious impulse of theirs, as they misunderstood an oracle that could only have signified Vespasian. They thus joined the ranks of excitable losers in the Croesus tradition. The Flavian triumph, we see from its multiple survivals, pictured the entire nation (gens) in revolt and justly defeated. Suetonius finds sufficient motive in a widespread eastern belief that a new ruler would come from Judaea at that time (eo tempore Iudaea profecti rerum potirentur), a foolish belief that caused Judaeans to kill their governor and begin the war (Vesp. 4.5). Tacitus takes much the same line, though he borrows more of Josephus'

Caesarea, and that Vespasian strategically arranged Egyptian support (War 4.602-21), rather ruining the Flavian story.

${ }^{20}$ Compare War 5.461 with Herodotus, Histories 1.32.7. 
omens and includes enough of the actual events to make the scheme problematic (Hist. 5.10). Still he elaborates Josephus' language about ambiguous oracles (ambages) misunderstood by this superstition-riddled gens so hostile to proper cultic remedies (5.13: gens superstitioni obnoxia, religionibus adversa). Incidentally, Suetonius and Tacitus prove that it was possible to mention oracles with neither author nor audience having a clue about any underlying text.

(iii) Josephus writes his War to undermine such gross Roman misunderstanding and denigration of the Judaeans as a foolish nation (1.1-8). His vivid portraits of ethnic strife, procuratorial provocations and responses to violence, presented with nuance and subtlety in rapidly changing conditions, show that Judaean statesmen such as himself are as good as any, but were faced with a kind of tyrant-led civil strife (stasis) that Romans know all too well from recent years. They are not so different. The moralising tidbit on misunderstood signs and oracles, in his final rant against the tyrants, cannot displace his main account of how the war actually unfolded. That story does not agree with Suetonius' claim that the Judaeans revolted because of a misunderstood oracle. He could hardly have recounted the long-simmering strife that blew up in Caesarea, or the mounting desperation in the face of the auxiliary cohorts' violence, and then added: 'And of course they were prompted by the great narrative of Deuteronomy and Daniel.' Such theological abstractions would not explain the intricately structured perfect storm that he portrays as the real cause of Cestius' and Vespasian's interventions. And are we to imagine that Judaeans themselves believed that one of their own would soon rule over the oikoumene?

If some readers respond, 'But he says that this oracle raised up the people for war', I must respond 'Yes, of course he does' - and then caution against mechanical readings of texts, taking no account of rhythms and devices. Yes, Josephus offers many foundations for war and causes of ruin, which cannot be systematically reconciled. ${ }^{21}$ Consider Life 41, where he makes Justus of Tiberias with his brother 'the cause of

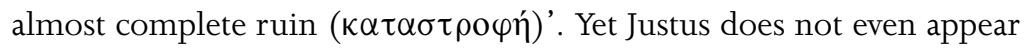
in War, and Josephus never names the brother or explains how they effected near 'ruin'. He makes this brief remark, but it is clearly part of his animus against Justus, and goes nowhere. Similarly, his remark about the misconstrued oracle is a passing comment in a passage of anti-tyrant venom, which has no traction in his account of the war's origins.

21 E.g. War 2.284, 409, 413; 4.318-25; Ant. 18.9-10; 20.166, 181, 210, 214, 218. 
(iv) This is not the only oracle or sign Josephus mentions, and the others are often so vague or imaginary (no one supposes that a cow gave birth to a lamb) as to be untraceable. Why choose this one alone, and insist that it points to the great narrative and Daniel, when Josephus mentions nothing of the kind? We have noted the neighbouring oracle about squaring the temenos. War uses $\chi \rho \eta \sigma \mu$ ós in two other places, both times accusing the tyrants of blindness. In 4.386-8 the narrator describes those who murder Ananus II and Jesus as trampling human laws, laughing at divine law and ridiculing prophetic oracles as mere beggars' babblings. Josephus appears to have a wide range of wellknown biblical promises in view (for virtue or vice) - not a narrative - but then mentions a particular ancient saying ( $\pi \alpha \lambda \alpha$ ı̀̀ $\lambda$ ó $\gamma \circ \varsigma$ ) that 'the city would be captured and the holiest place would be burned down by the law of war if one should embark on civil war ( $\sigma \tau \alpha$ ó $\sigma$ ) and native hands should pollute the sacred precinct of God' (4.388). He seems to have related thoughts (passages?) in view at 6.109, in a brief speech to the tyrants: 'Who did not know what was written up in the ancient prophets [the clear "oracles" above], and especially the oracle about to be realised now in this miserable city ( $\tau \tilde{n} \tau \lambda \eta \dot{\mu} \mu \nu \iota \pi$ ó $\lambda \varepsilon \iota)$ : that they foretold its capture when someone would resort to compatriot murder.'

So on the one hand, Josephus' 'oracles' are clear biblical predictions of reward for virtue and punishment for vice, which everyone must know (e.g. Ant. 4.313). On the other hand, he likes to gild the lily with supposedly precise predictions that no one has been able to find in the

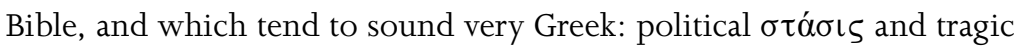
pollution from compatriot bloodshed - the tragic mood signalled by a word such as $\tau \lambda \eta \dot{\mu} \omega \nu{ }^{22}$ Again, why should we should take War 6.312, alone and out of context, described as a misconstrued oracle (not a clear biblical expectation), to indicate a scriptural story so well known that it led people to war? Josephus' contrast between his esoteric knowledge and the folly of others does not make this promising.

(v) None of this is to deny Josephus' interest in Daniel. He was clearly invested in scripture and - innocent of Porphyry's proof that the author predicted ex eventu ${ }^{23}$ - offered Daniel's predictions as evidence of its potency (Ant. 10.266-7). He rejuvenated the fourth kingdom of Nebuchadnezzar's dream as iron only, so that Rome fit the role

22 Of the only 752 occurrences of this word in more than 10,000 Thesaurus Linguae Graecae texts, 187 are from Aeschylus, Euripides and Sophocles.

23 In Jerome, Comm. Dan. praef. et passim. 
(Ant. 10.205-10, 276), and he might well have come to see the tenth horn of the fourth beast in Daniel 7 as Vespasian - with Caesar as first horn - from Vespasian's rise in 69. Why not? But since the fourth kingdom would be pulverised (he intensifies Daniel's language) by a stone, and the horns of the fourth beast would be utterly destroyed by a human-like figure granted eternal dominion, no one could have confused the fourth kingdom with the stone, or the tenth horn with the Son of Man. These passages are therefore unlikely sources of oracle confusion. It is much easier to suppose Josephus makes this up (as so much else) as he goes along. More generally, the bilingual and multi-genre book of Daniel, given the demonstrable variety of its later uses, seems a particularly unstable candidate for repository of the great narrative.

\section{Conclusions}

This fourth volume in N. T. Wright's great synthesis of Christian origins is another stunner. It shows again a prodigious intellect indefatigably processing oceans of primary text and scholarly literature, and it has understandably found a large and appreciative audience. I was invited to probe its treatment of ancient Judaism. Focusing on aspects of Paul's Pharisaic background and the controlling narrative of exile that Wright posits for ancient Jews generally, I hope to have shown why I cannot support these parts of the foundation. All historians must imagine the scenarios that produced our surviving evidence. My critique lies precisely there: in finding it difficult to see how the ancient situations and outlooks described by Wright would explain Philo, Josephus or rabbinic literature, read contextually. 